\title{
EXPERIMENTAL AND NUMERICAL ANALYSIS OF SPRINGBACK PREDICTION IN U-BENDINGS OF ANISOTROPIC SHEET METALS
}

\begin{abstract}
Springback is one of the most important problems that should be taken into consideration during design of sheet metal forming process with the increasing application of advanced high strength steels and light-weight alloys. The degree of springback experienced with the latest generation materials is so high, and the materials so strong, that it is not possible to eliminate the springback in the prototyping. It becomes mandatory to compensate for springback as part of the draw die design, which is usually carried out through numerical simulation. The springback behavior of three categories of sheet steels (TRIP, HSLA and mild steel) with thicknesses ranging from 0.75 to $0.85 \mathrm{~mm}$ was investigated by means of the cyclic U-bending test. This phenomenon can be defined as an elastically-driven change of shape of the deformed part upon removal of external loads. Steel sheets were bent on the two different die radii and after first cycle were bent reverse. The influence of die radius on amount of springback of the steels was considered. Value of the springback angle change after the first and second cycle was measured. The change of values of angles between cycles is caused by the Bauschinger effect. This process was investigated experimentally and numerically. Numerical investigation was performed in static implicit finite element code Autoform.
\end{abstract}

Keywords: Baushinger effect, bending, cyclic bending, springback

\section{Introduction}

In the metal stamping industry, one of the major technological problems is getting the sheet metal to conform exactly to the shape of the die. Due to the effects of springback, die designs are usually finalized only after the fabrication and testing of multiple prototypes [1-3]. The main effects of springback on the formed parts are as follows: the alteration of the part shape and dimensions after

\footnotetext{
${ }^{1}$ Autor do korespondencji/corresponding author: Jan Slota, Technical University in Košice, 74 Mäsiarska St., 04001 Košice, Slovakia, tel. +421 55 6023502, e-mail: jan.slota@tuke.sk

${ }^{2}$ Miroslav Jurčišin, e-mail: miroslav.jurcisin@ tuke.sk

${ }^{3}$ Milan Dvořák, e-mail: dvorak.m@fme.vutbr.cz
} 
tools removing and also the change of the state of stresses and strains in the deformed material [2-4]. The determination, elimination or avoidance of the defects generated by springback requires the analysis and knowledge of its specific causes and its relation with different factors of influence [5-11]. Among the factors which influence the amount of springback belongs for example: mechanical properties of material, friction coefficient, die gap, die radius, blankholder force, bending curvature etc. Since springback cause also problems associated with economical aspect, it is necessary to predict it. This can be realized using analytical, empirical and also numerical methods. Nowadays finite element method is very frequently used method of numerical simulation as a tool of springback compensation, but this is also associated with problems of neglecting and simplifying of important parameters during definition of material models. In this paper bending process of sheet metals on the different radiuses to the angle of $180^{\circ}$ in order to extend existing knowledge was realized. Several publications were also devoted to the problem of cyclic bending, namely in connection with the influence of the Bauschinger effect on the springback amount. Gau and Kinzel [12] studied the influence of the Bauschinger effect to the springback and concluded that two identical sheet metal specimens can have the same final total strains but they can have distinctly different springback amounts. The reason is that their deformation histories in the strain space are different. The Bauschinger effect on springback depends not only on the material type but also on the deformation history in the strain area [12]. The bending process was modeled in finite element code Autoform. This software works on basis of static implicit time integration scheme. As it was mentioned, software works with implicit time integration strategy which is in every time step starting from the previous time step and a mesh is generated using local refinement due to requiring accuracy of problem, which is calculated resulting from current mesh. This solving process is iterated until the estimated error value was in the range of the interval of requiring precision. If the time step between new iteration and previous is not too large, the time of solving process is usually very short [13]. The blank material defined in the numerical simulation was in the case of yield function approximated using Hollomon hardening curve $\sigma=C \varepsilon^{n}$ and Hill' 48 yield function which is defined by following law [14]:

$$
\begin{aligned}
\phi\left(\sigma_{i j}\right)= & F\left(\sigma_{22}-\sigma_{33}\right)^{2}+G\left(\sigma_{33}-\sigma_{11}\right)^{2}+H\left(\sigma_{11}-\sigma_{22}\right)^{2}+ \\
& +2 L \sigma_{23}^{2}+2 M \sigma_{31}^{2}+2 N \sigma_{12}^{2}-\bar{\sigma}^{2}=0
\end{aligned}
$$

where: $\phi\left(\sigma_{i j}\right)$ - stress components with respect to the coordinate system [MPa], $F, G, H, L, M, N$ - Hill's anisotropic parameters, which can be expressed by normal anisotropy, $\sigma_{22}, \sigma_{33}, \sigma_{11}, \sigma_{23}, \sigma_{31}, \sigma_{12}$ - plane stresses; suffix 1 is parallel to the rolling direction, 2 is transverse to the rolling direction, $\bar{\sigma}$ is scaling factor. 


$$
F=\frac{r_{0}}{r_{90}\left(r_{0}+1\right)}, G=\frac{1}{r_{0}+1}, H=\frac{r_{0}}{r_{0}+1}, N=\frac{\left(r_{0}+r_{90}\right)\left(1+2 r_{45}\right)}{2 r_{90}\left(1+r_{0}\right)}
$$

where: $r_{0}, r_{45}, r_{90}$ - values of normal anisotropy measured in directions $0^{\circ}, 45^{\circ}$ and $90^{\circ}$ respectively to the rolling direction; $L, M$ - coefficients which are equal to the $N$.

\section{Experimental procedure}

The experiments of bending sheet metal strips focused on the measuring of the springback amount were performed. Dimensions of specimens were $20 \times 120$ $\mathrm{mm}$ and all specimens were cut parallel to the rolling direction. The device for springback testing was developed at the Brno University of Technology and the picture of this device is shown in Fig. 1. Schematic view of this experiment is presented in Fig. 2a. Two different die radiuses R 11 and R 17 were used. First of all, in the first cycle, the specimen was bent over the die and after bending, the value of the springback angle was measured. Then, in the second cycle, the specimen was positioned and bent again over the die and the value of the springback angle was measured. The angle of springback $\beta$ is shown in Fig. $2 b$. Realization of this experiment was divided into the following stages:

- bending the sheet metal strips on the different die radii,

- bending the sheet metal strips to the angle of $180^{\circ}$, measuring springback and subsequently bending this strip to the angle $180^{\circ}$ in the reverse direction and again measuring springback,

- modelling of the process of the first cycle in finite element $(F E)$ software and comparing the results of springback with experiment.

Fig. 1. The experimental device for determination of the springback angle

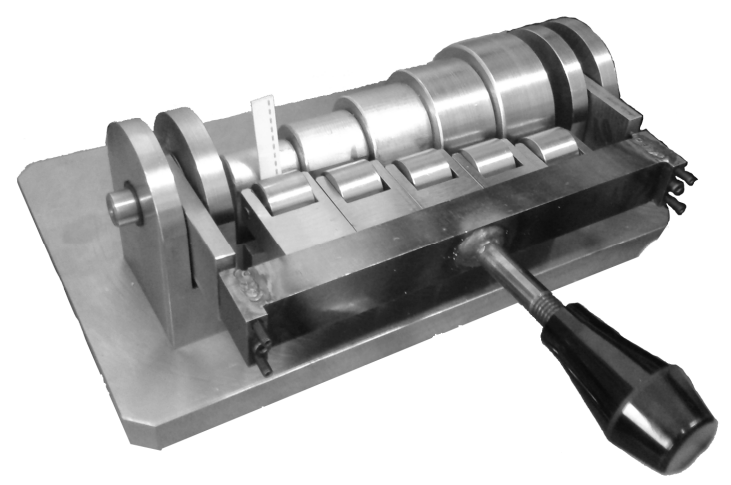


a)

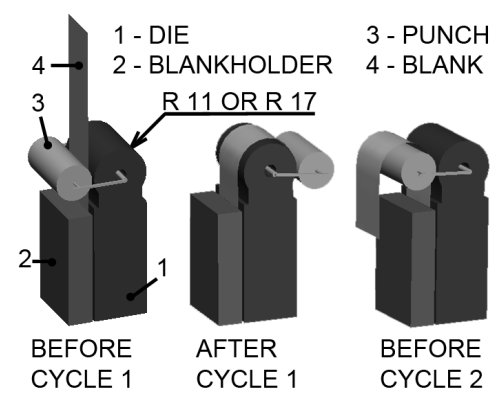

b)

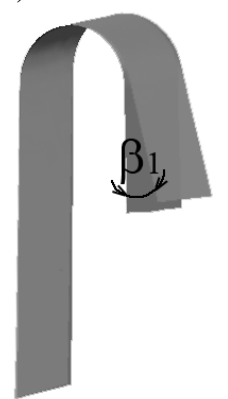

Fig. 2. Geometry of the device (a) and the illustration of the springback angle $\beta$ (b)

The amount of springback significantly depends on used materials. For this experiment three grades of steels were used:

- steel of DQ category DC06 with thickness of $0.85 \mathrm{~mm}$,

- AHS steel HSLA 220PD with thickness of $0.8 \mathrm{~mm}$,

- UHS steel TRIP RAK 40/70 with the thickness of $0.75 \mathrm{~mm}$. Mechanical properties of these steels are presented in Table 1 .

Table 1. Mechanical properties of the sheet metal used in the experiment

\begin{tabular}{|c|c|c|c|c|c|c|c|}
\hline $\begin{array}{c}\text { Sheet } \\
\text { material }\end{array}$ & $\begin{array}{c}\text { Specimen } \\
\text { orientation }\end{array}$ & $\begin{array}{c}\boldsymbol{R}_{p 0.2}\left(R_{e}\right) \\
{[\mathrm{MPa}]}\end{array}$ & $\begin{array}{c}\boldsymbol{R}_{m} \\
{[\mathrm{MPa}]}\end{array}$ & $\begin{array}{l}A_{80} \\
{[\%]}\end{array}$ & $n$ & $\begin{array}{c}C \\
{[\mathrm{MPa}]}\end{array}$ & $r$ \\
\hline \multirow{3}{*}{$\begin{array}{c}\text { DC06 } \\
\text { mild steel }\end{array}$} & $0^{\circ}$ & 138 & 277 & 53.0 & \multirow{3}{*}{0.261} & \multirow{3}{*}{538} & 1.665 \\
\hline & $45^{\circ}$ & 142 & 282 & 50.4 & & & 1.601 \\
\hline & $90^{\circ}$ & 141 & 277 & 51.7 & & & 2.112 \\
\hline \multirow{3}{*}{$\begin{array}{l}\text { UHSS } \\
\text { TRIP } \\
\text { RAK } \\
40 / 70 \\
\end{array}$} & $0^{\circ}$ & 442 & 771 & 27.7 & \multirow{3}{*}{0.29} & \multirow{3}{*}{1492} & 0.686 \\
\hline & $45^{\circ}$ & 441 & 762 & 25.4 & & & 0.87 \\
\hline & $90^{\circ}$ & 450 & 766 & 25.9 & & & 0.838 \\
\hline \multirow{3}{*}{$\begin{array}{c}\text { HSS } \\
\text { H220PD }\end{array}$} & $0^{\circ}$ & 219 & 385 & 34.5 & \multirow{3}{*}{0.231} & \multirow{3}{*}{673} & 1.172 \\
\hline & $45^{\circ}$ & 225 & 368 & 37.4 & & & 1.782 \\
\hline & $90^{\circ}$ & 238 & 383 & 35.8 & & & 1.823 \\
\hline
\end{tabular}

Due to difficulty of using conventional methods, measurement of the value of the angle $\beta$ after springback was performed using MATLAB system. The springback angle value can be calculated and evaluated accurately using measuring method implemented in MATLAB $[11,15]$. Five points on the each arm of the specimen were selected. After points were selected, linear regression was used to reach equation of straight line for each arm of the specimen. Based on 
equations of straight lines, the value of the angle between them was computed. As it was mentioned, the first cycle of this process was modeled in the static implicit code Autoform. Parameters set in the numerical simulation of this process are described in Table 2.

Table 2. Parameters of the implicit code Autoform

\begin{tabular}{|l|c|c|c|}
\hline \multicolumn{1}{|c|}{ Parameter } & Value & Parameter & Value \\
\hline Mesh type & triangular & element type & shell \\
\hline Mesh size & $0.75 \mathrm{~mm}$ & friction value & 0 \\
\hline Level of refinement & 2 & yield curve & Hill' 48 \\
\hline Mesh size after refinement & $0.375 \mathrm{~mm}$ & hardening curve & hollomon \\
\hline Number of integration points & 11 & tool mesh & $0.5 \mathrm{~mm}$ \\
\hline
\end{tabular}

\section{Results and discussion}

In Table 3 results of the springback measuring of specimen made of TRIP steel are presented. Since, only the first cycle was modeled in the $F E$ code, for the second cycle results of the numerical simulation will be not presented. $\beta_{1}$ is the angle of springback after the first cycle and $\beta_{2}$ is the angle of springback after the second cycle. $\beta_{1 \mathrm{~s}}$ is the angle of springback after first cycle obtained from the numerical simulation. A difference between angles values of springback after the first and second cycle in experiment is $\beta_{D}$ and it is calculated using following formula:

$$
\beta_{D}=\beta_{2}-\beta_{1}
$$

Because TRIP steel has the highest strength, the highest amount of springback was measured. Results of the numerical simulation of springback for TRIP and H220PD steels were insufficient. In the case of TRIP steel the greatest difference was observed. This is caused by difficulty of definition of material structure and transformation of residual austenite to martensite. Numerical modeling of the U-bending test for conventional DC06 steel was the most accurate in comparison with the result of the real experiment. In the case of the measurement of the springback angle value after second cycle for TRIP steel increasing in the value of springback angle value was observed. For H220PD and DC06 steel in the same cycle the value of springback angle decreasing. This was caused by the transformation process of the austenite to the martensite. So, TRIP steel has become stronger and thus, greater springback was observed. Conventional steels as H220PD and DC06 did not undergo this transformation and therefore there was observed smaller springback. 
Table 3. Results of springback for TRIP RAK 40/70 steel

\begin{tabular}{|c|c|c|c|}
\hline \multirow{2}{*}{ Cycle } & Experiment & Difference between cycles & Simulation \\
\hline & $\beta_{1}\left[{ }^{\circ}\right] / \beta_{2}\left[{ }^{\circ}\right]$ & $\boldsymbol{\beta}_{\boldsymbol{D}}\left[{ }^{\circ}\right]$ & $\boldsymbol{\beta}_{1 \mathrm{~s}}\left[{ }^{\circ}\right]$ \\
\hline \multicolumn{4}{|c|}{ Die radius - R 11} \\
\hline 1 & 43 & \multirow{2}{*}{2.5} & \multirow{2}{*}{20.6} \\
\hline 2 & 45.5 & & \\
\hline \multicolumn{4}{|c|}{ Die radius - R 17} \\
\hline 1 & 39.3 & \multirow{2}{*}{1.9} & \multirow{2}{*}{25.4} \\
\hline 2 & 41.2 & & \\
\hline
\end{tabular}

Table 4. Results of springback for H220PD steel

\begin{tabular}{|c|c|c|c|}
\hline \multirow{2}{*}{ Cycle } & Experiment & Difference between cycles & Simulation \\
\cline { 2 - 4 } & $\left.\boldsymbol{\beta}_{\mathbf{1}}\left[{ }^{\circ}\right] / \boldsymbol{\beta}_{\mathbf{2}}{ }^{\circ}{ }^{\circ}\right]$ & $\left.\boldsymbol{\beta}_{\boldsymbol{D}}{ }^{\circ}{ }^{\circ}\right]$ & $\left.\boldsymbol{\beta}_{\mathbf{1 s}}{ }^{\circ}\right]$ \\
\hline \multicolumn{5}{|c|}{ Die radius - R 11 } \\
\hline 1 & 21.1 & -2.9 & 14.5 \\
\hline 2 & 18.2 & -1.9 & 10.7 \\
\hline \multicolumn{5}{|r|}{ Die radius - R 17 } \\
\hline 1 & 17.5 & \multicolumn{2}{|c}{} \\
\hline 2 & 16.3 &
\end{tabular}

Table 5. Results of springback for DC06 steel

\begin{tabular}{|c|c|c|c|}
\hline \multirow{2}{*}{ Cycle } & Experiment & Difference between cycles & Simulation \\
\cline { 2 - 4 } & $\boldsymbol{\beta}_{\mathbf{1}}\left[^{\circ}\right] / \boldsymbol{\beta}_{\mathbf{2}}\left[^{\circ}\right]$ & $\boldsymbol{\beta}_{\boldsymbol{D}}\left[^{\circ}\right]$ & $\boldsymbol{\beta}_{\mathbf{1 s}}\left[^{\circ}\right]$ \\
\hline \multicolumn{5}{|c|}{ Die radius - R 11 } \\
\hline 1 & 14.1 & 0.7 & 12.1 \\
\hline 2 & 14.8 & Die radius - R 17 \\
\hline \multicolumn{5}{|c}{-2.3} & \multirow{2}{*}{8.6} \\
\hline 1 & 8.8 & & \\
\hline 2 & 6.5 &
\end{tabular}

Although, there is the publication which claims that the influence of the Bauschinger effect on the springback is observed especially in the case of the use aluminum materials [12], as it is presented in Tables 3-5, influence of the 
Bauschinger effect on springback was observed also in the case of steel specimens. Higher value of springback occurred in the case of smaller die radius with DC06 and H220PD steels. Since smaller die radius caused higher value of stress in the area of bent section, greater value of springback was observed. Difference in major stress over the section of the specimen made of DC06 steel is shown in Fig. 3. Different amount of major stress was measured for TRIP steel specimen. In case of the die radius $\mathrm{R} 11$ maximum value of major stress was $574 \mathrm{MPa}$. The evaluated stress in the case of die radius $\mathrm{R} 17$ was $584 \mathrm{MPa}$. Therefore, higher amount of springback was observed in the case of die radius R 17.

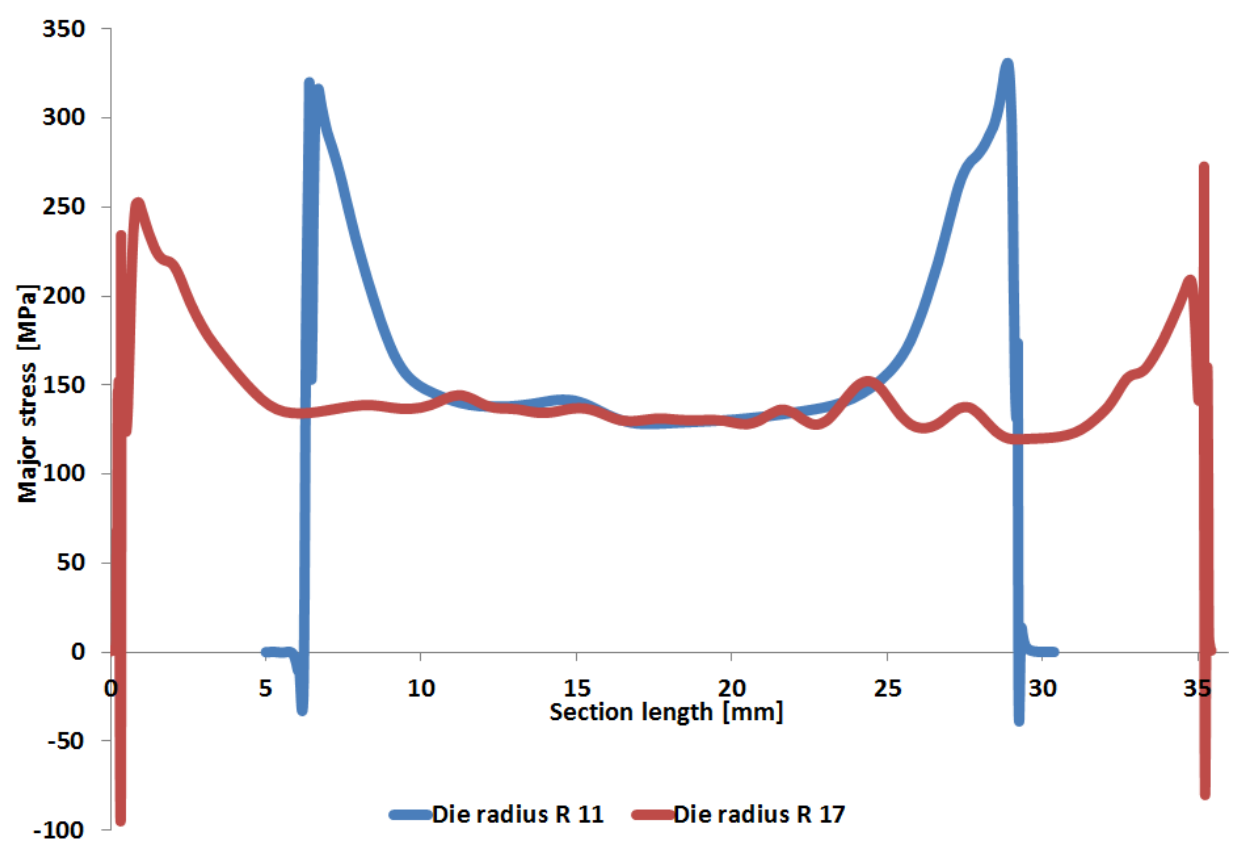

Fig. 3. Major stress over the section on the bottom layer for specimen made of DC06 steel

\section{Conclusions} noted:

Based on results presented in this paper, following conclusions could be

1. This experiment confirmed that the forming of high strength steels is associated mainly with springback problems.

2. In the case of DC06 and H220PD steels, greater die radius caused smaller amount of springback, because greater die radius causes smaller major stresses in comparison with smaller die radius. Situation was different for specimen made of TRIP steel. 
3. The Numerical simulation was sufficient only in the case where DC06 steel was used. In case of TRIP and H220PD steels, the simulation of springback was not accurate enough. This problem may be solved using modern material models which consider mixed hardening, apparent Young's modulus, the Bauschinger effect, permanent softening etc.

4. Influence of the Bauschinger effect on springback amount was observed after the second cycle of bending. In case of TRIP steel, the Bauschinger effect caused the increase of value of springback because transformed martensite increased total strength of the material. With DC06 and H220PD smaller amount of springback after the second cycle was observed.

\section{References}

[1] Ling Y.E., Lee H.P., Cheok B.T.: Finite element analysis of springback in L-bending of sheet metal. J. Mat. Proc. Technol., 168 (2005), 296-302.

[2] Wagoner R.H., Lim H., Lee M.G.: Advanced issues in springback. Int. J. Plasticity, 45 (2013), 3-20.

[3] Hu Y.: Simulating the die gap effect on springback behavior in stamping processes. SAE Technical Paper 2000-01-1111.

[4] Brabie G., Chirita B., Nanu N., Ciubotariu V.: Analysis of the springback and residual stresses generated by cold plastic forming in draw round parts made from steel sheets. Met. Int., 12-14 (2009), 21-27.

[5] Stachowicz F., Frącz W.: An experimental and numerical study of thin sheet metal bending. Trans. TAU, 9 (2002), 177-180.

[6] Stachowicz F., Litwin P., Frącz W.: Experimental and numerical study of open structural profile bending process. Arch. Metall. Mater., 50 (2005), 905-919.

[7] Frącz W., Stachowicz F.: Springback phenomenon in sheet metal V-die air bending - experimental and numerical study. Manuf. Eng., 7 (2008), 34-37.

[8] Frącz W., Litwin P., Stachowicz F.: Analysis of bending characteristics of open structural profile. 18th Int. Conf. Computer Methods in Mechanics, Zielona Góra 2009, 177-178.

[9] Su C.J., Zhang G.H., Guo S.M., Gao L., Ma R.: Influence of friction on springback of quadrangle parts bending. Adv. Mat. Res., 217-218 (2011), 619-624.

[10] Nanu N., Brabie G.: Analytical model for prediction of springback parameters in the case of $U$ stretch-bending process as a function of stresses distribution in the sheet thickness. Int. J. Mech. Sci., 64 (2012), 11-21.

[11] Slota J., Jurčišin M., Spisak E.: Numerical and experimental springback determination of sheet metals in an air bending process. Acta Metallurgica Slovaca, 18 (2012), 200-209.

[12] Gau J.T., Kinzel G.L.: An experimental investigation of the influence of the Bauschinger effect on springback predictions. J. Mat. Proc. Technol., 108 (2001), 369375. 
[13] Schmidt A., Kunibert G.S.: Design of adaptive finite element software. The finite element toolbox. Universitat Bremen, Bremen 2004.

[14] Banabic D.: Sheet metal forming processes. Constitutive modeling and numerical simulation. Springer, London 2010.

[15] Kardes Sever N., Mete O.H., Demiralp Y., Choi C., Altan T.: Springback prediction in bending of AHSS-DP-780. Proc. NAMRI/SME, vol. 40, 2012.

\section{Acknowledgement}

This contribution is the result of the project VEGA 1/0396/11 implementation.

\section{BADANIA EKSPERYMENTALNE I NUMERYCZNE SPRĘŻYNOWANIA PODCZAS WZGINANIA BLACH ANIZOTROPO- WYCH}

\section{Streszczenie}

Sprężynowanie jest jednym z głównych problemów, które powinny być uwzględniane podczas projektowania procesów kształtowania coraz częściej stosowanych blach stalowych wysokowytrzymałych i wytwarzanych ze stopów lekkich. Stopień sprężynowania obserwowany podczas badań eksperymentalnych niedawno opracowanych gatunków materiałów jest tak wysoki, przy jednoczesnej dużej wytrzymałości tych materiałów, że nie jest możliwe wyeliminowanie sprężynowania na etapie prototypowania. Kompensacja sprężynowania jest więc obowiązkowa i jest częścią procesu projektowania narzędzia, co jest zwykle przeprowadzane za pomocą symulacji numerycznej. Badano sprężynowanie trzech gatunków blach (TRIP, HSLA i stal miękka) o grubościach od 0,75 do $0,85 \mathrm{~mm}$ za pomocą testu U-gięcia. Sprężynowanie może być zdefiniowane jako sprężysta zmiana kształtu odkształconej części po usunięciu obciążenia zewnętrznego. Blachy stalowe gięto za pomocą matryc o dwóch różnych promieniach. Po zakończeniu pierwszego cyklu gięcia blachy były gięte w kierunku przeciwnym. Analizowano wpływ promienia matrycy na wartość sprężynowania. Wartość kąta sprężynowania mierzono po pierwszym i drugim cyklu gięcia. Zmiana wartości kątów pomiędzy tymi cyklami jest określana jako efekt Bauschingera. Proces gięcia badano eksperymentalnie i numerycznie za pomocą programu do obliczeń metodą elementów skończonych Autoform z procedurą static implicit.

Słowa kluczowe: efekt Baushingera, gięcie, gięcie cykliczne, sprężynowanie

DOI:10.7862/rm.2013.47

Otrzymano/received: $15.09 .2013 \mathrm{r}$.

Zaakceptowano/accepted: 22.11.2013 r. 